\title{
Benthic community composition across gradients of intertidal elevation, wave exposure, and ice scour in Atlantic Canada
}

\author{
Christine S. Heaven, Ricardo A. Scrosati* \\ Saint Francis Xavier University, Department of Biology, Antigonish, Nova Scotia B2G 2W5, Canada
}

\begin{abstract}
Studies on community organization may focus on different properties, such as species richness (total number of species) or composition (a measure of the identity and abundance of species). In rocky intertidal habitats from Nova Scotia, Canada, we previously determined that richness varied across vertical (elevation) and horizontal (wave/ice exposure) gradients of environmental stress on 2 coasts of contrasting winter ice load: the Gulf of St. Lawrence coast and the open Atlantic coast. Across some limited ranges of stress, however, richness remained similar. Through multivariate analyses (NMDS followed by ANOSIM) of species abundance data measured for all seaweeds and benthic invertebrates, we increased our ability to detect spatial trends in community structure. The present study shows that community composition varied clearly across all studied ranges of environmental stress. Therefore, even relatively small changes in abiotic stress seem capable of altering the structure of intertidal communities. An analysis of similarity percentages (SIMPER) identified the main species that typified each environmental level and those that best discriminated between consecutive levels across the elevation and exposure gradients. Sessile organisms (barnacles and a few brown and red seaweeds) constituted the most important characterizing species, with differences in relative importance between the 2 studied coasts. Future experimental work aiming to unravel the biotic interactions underlying the observed changes in composition across the stress gradients should benefit by initially focusing on these species.
\end{abstract}

KEY WORDS: Community composition · Ice scour · Intertidal elevation · Rocky shore · Wave exposure

Resale or republication not permitted without written consent of the publisher

\section{INTRODUCTION}

Understanding how communities are structured across space is an important goal of ecology. Environmental stress refers to the negative forcing that the abiotic environment exerts on the performance of organisms. Spatial changes in environmental stress can have major effects on community structure through a variety of effects on biotic interactions, including predation, competition and facilitation (Bruno et al. 2003). In rocky intertidal habitats, the main gradients of environmental stress occur vertically across elevation and horizontally across areas differing in wave exposure and, at high latitudes, ice scour intensity.
Along the vertical intertidal gradient, abiotic stresses related to temperature, desiccation, irradiance, and osmotic potential increase with elevation because of tides (Raffaelli \& Hawkins 1996). The regular alternation of high and low tides determines that the above factors depict an increasing range of temporal variability as elevation increases, resulting in their most extreme values occurring at the high intertidal zone because of its longer exposure to the air. As a result, for a given intertidal biota considered as a whole, environmental conditions become increasingly harsher as elevation increases (Stachowicz 2001, Benedetti-Cecchi et al. 2006, Garbary 2007). Thus, vertical gradients of environmental stress constitute a major factor affecting 
the distribution of organisms across elevation (Menge $\&$ Branch 2001). Horizontal differences in wave exposure can also influence community organization dramatically. Wave action may dislodge invertebrates and algae, and influence their size, structure, and recruitment (Denny 1995, Helmuth \& Denny 2003). On polar and subpolar shores, horizontal differences in ice scour intensity may also affect the structure of intertidal communities. The abundance and movement of floating ice, or fast ice (Barnes 1999), affects the degree of ice scour on the coast, thereby affecting the intensity of physical disturbance imposed on communities (Bolton 1983, Gutt 2001, Johnson 2007). Because of local patterns in coastal topography, the intensity of ice scour may be spatially correlated with the degree of wave exposure (Scrosati \& Heaven 2007).

NW Atlantic rocky shores have traditionally been useful model systems to study factors affecting community structure (Menge \& Branch 2001, Bertness et al. 2004). However, most studies have been done in New England, on the NE coast of the United States, with fewer studies done on more northern shores, such as those in Atlantic Canada (Chapman \& Johnson 1990, Adey \& Hayek 2005). For a given regional pool of species, regional gradients of environmental stress are known to influence community organization (Huston 1994). On the Atlantic coast of Canada, winter conditions are harsher than in New England (Bertness 2007). Thus, it is important to understand how rocky intertidal communities are related to such increased levels of stress. For this reason, we quantified the abundance of all intertidal seaweeds and invertebrates across vertical and horizontal gradients of abiotic stress on 2 coasts in Nova Scotia with contrasting winter ice load. An environmental stress model proposed by Menge \& Sutherland (1987) and developed further by Bruno et al. (2003) was successful in predicting general trends in richness (total number of species) across the studied gradients of stress on both coasts (Scrosati \& Heaven 2007). However, for some limited ranges of stress, species richness did not vary significantly, suggesting that environmental stress may not affect community structure unless pronounced changes in the abiotic environment occur.

Species composition is a combined measure of the identity and abundance of species in a community. As such, it synthesizes more information about a community than species richness. In fact, nearby communities showing the same richness may greatly differ in composition (Tuomisto \& Ruokolainen 2006). Therefore, we decided to further examine the effects of intertidal stress gradients on benthic community structure by determining the spatial trends in composition across such gradients. Determining the spatial patterns in composition, in addition to richness patterns, is important because both properties affect ecosystem function in often-unrelated ways (Downing \& Leibold 2002, Tilman et al. 2003, Sullivan et al. 2007). We also found it interesting to identify the main species characterizing the spatial structure of community composition in the studied habitats. This is important to know as a first step (Underwood et al. 2000) towards identifying the species that might have the largest structuring effects on communities across the stress gradients. Thus, in the present study, we asked the following questions: (1) Does intertidal species composition change across vertical (elevation) and horizontal (wave/ice exposure) environmental gradients on the 2 studied shores in Nova Scotia? and (2) What are the main species that characterize the compositional similarity within elevation/exposure levels and dissimilarity between levels?

\section{MATERIALS AND METHODS}

Study sites. We took measurements at Sea Spray Shore $\left(45^{\circ} 46^{\prime} 22^{\prime \prime}\right.$ to $23^{\prime \prime}$ N, $62^{\circ} 8^{\prime} 39^{\prime \prime}$ to $41^{\prime \prime}$ W; hereafter $\mathrm{SS}$ ), on the Gulf of St. Lawrence coast of Nova Scotia, and at Tor Bay Provincial Park $\left(45^{\circ} 10^{\prime} 57^{\prime \prime}\right.$ to $58^{\prime \prime} \mathrm{N}$, $61^{\circ} 21^{\prime} 17^{\prime \prime}$ to $22^{\prime \prime} \mathrm{W}$; hereafter TB), on the open Atlantic coast of Nova Scotia, Canada. These sites were selected mainly because of their convenient accessibility by land. Before selecting the sites, we did preliminary surveys along approximately $500 \mathrm{~km}$ of coastline (between the Gulf and Atlantic coasts combined) and found that, based on the abundance of the most common species (barnacles and fucoid algae) viewed at coarse spatial scales, SS and TB look biologically similar to physically similar sites along the surveyed range on the Gulf and Atlantic coasts, respectively. We only surveyed sites with stable bedrock (not boulder fields), which consisted of volcanic rock at SS and metamorphose sedimentary rock at TB. Surface seawater temperature varies between monthly means of -1.4 and $18.2^{\circ} \mathrm{C}$ in the SS region, and -0.3 and $16.9^{\circ} \mathrm{C}$ in the $\mathrm{TB}$ region, while surface seawater salinity varies between monthly means of 28.4 and $30.6 \%$ in the SS region, and 29.5 and $31.4 \%$ in the TB region (Fisheries and Oceans Canada 2008a). In the summer and fall of 2005, we measured a maximum seawater temperature of $21^{\circ} \mathrm{C}$ at SS (August) and $20.5^{\circ} \mathrm{C}$ at TB (September) and a maximum salinity of $32 \%$ at SS (October-November) and 35\% at TB (October).

Environmental gradients. We sampled the full intertidal range (vertical gradient) at both sites, between $0 \mathrm{~m}$ (chart datum) and an upper boundary that we determined using ecological indicators (the barnacle Semibalanus balanoides) to account for the fact that zones with similar emersion-related stresses are higher and wider in wave-exposed habitats than in sheltered habitats (Harley \& Helmuth 2003). This barnacle is the sessile, perennial species occurring highest on the 
shore anywhere at SS and TB, which ensured that annual and seasonal wave regimes were integrated when determining upper intertidal boundaries using this indicator. Once we determined the upper boundary for our study areas, we divided the intertidal range into 3 zones of equal vertical extent (high, mid, and low zones). Wave exposure (horizontal gradient) is generally lower on the Gulf of St. Lawrence coast than on the Atlantic coast (Fisheries and Oceans Canada 2008b). Thus, 2 exposure levels were selected for SS (sheltered and exposed) and 3 levels for TB (sheltered, intermediate, and exposed). At SS, maximum water velocity averaged $3.4 \mathrm{~m} \mathrm{~s}^{-1}$ in sheltered areas and $5.2 \mathrm{~m} \mathrm{~s}^{-1}$ in exposed areas over several $24 \mathrm{~h}$ periods surveyed between the summer and autumn seasons of 2005. At TB, maximum water velocity averaged $4.3 \mathrm{~m} \mathrm{~s}^{-1}$ in sheltered areas, $6.5 \mathrm{~m} \mathrm{~s}^{-1}$ in areas subjected to intermediate exposure, and $7.5 \mathrm{~m} \mathrm{~s}^{-1}$ in exposed areas during the same period (see highest and lowest values of exposure in Scrosati \& Heaven 2007). The upper intertidal boundary, as defined above relative to chart datum, was $1.66 \mathrm{~m}$ (sheltered) and $1.70 \mathrm{~m}$ (exposed) at $\mathrm{SS}$, and $1.56 \mathrm{~m}$ (sheltered), $1.99 \mathrm{~m}$ (intermediate exposure) and $2.16 \mathrm{~m}$ (exposed) at TB. Significant ice scour occurs every year only on the Gulf of St. Lawrence coast. The open Atlantic coast does not experience local formation of ice on the sea surface, and ice scour due to floating ice coming from the Gulf of St. Lawrence occurs only at intervals of several years (Minchinton et al. 1997). On the Gulf coast, sea ice forms in early winter and melts in late winter and early spring (Saucier et al. 2003, Scrosati \& Eckersley 2007). Measurement of the damage (angle of deformation) caused by sea ice to metallic cages affixed to the rocky substrate at SS indicated that ice scour is strong (mean angle of deformation of $90^{\circ}$ ) on wave-exposed areas and relatively mild (mean angle of $47^{\circ}$ ) on wavesheltered areas (Scrosati \& Heaven 2006). Thus, the 2 levels used for wave exposure at SS also represented differences in ice scour intensity. For simplicity hereafter, for SS the term 'exposed' will refer to high levels of wave exposure and ice scour, whereas the term 'sheltered' will refer to low levels in both variables.

Species abundance. We measured the abundance of all seaweeds and benthic invertebrates for each combination of elevation and exposure (6 combinations for SS and 9 for TB) between 8 July and 21 August 2005, when species richness was highest for the year. For each combination, we determined the percent cover of each species in twenty $625 \mathrm{~cm}^{2}(25 \times 25 \mathrm{~cm})$ random quadrats divided in 100 subquadrats with monofilament line. The spatial coordinates of each transect line along which the quadrats were placed are given in Heaven (2006). We identified species using field guides (Gibson 2003, Martínez 2003) and taxonomic keys (Pollock 1998, Sears 1998, Villalard-Bohnsack 2003). The complete list of the identified taxa was published in Scrosati \& Heaven (2007).

Data analysis. For each coast, the abundances of all species were analyzed as a multivariate data set using PRIMER v. 6 (Clarke \& Warwick 2001), with 120 samples (3 elevation levels $\times 2$ exposure levels $\times 20$ replicates) for SS and 180 samples (3 elevation levels $\times 3$ exposure levels $\times 20$ replicates) for TB. Resemblance patterns among the samples (quadrats) were observed using non-metric multidimensional scaling (NMDS; Clarke 1993). This ordination technique is appropriate for ecological data, which often have numerous zeroes (absence of a species in a sample; Clarke \& Warwick 2001). We used the Bray-Curtis similarity coefficient to quantify the similarity between all pairs of samples (Clarke \& Warwick 2001), using untransformed data because there were no assumptions to meet for this analysis (Anderson 2001) and because there were no hypotheses requiring an arbitrary reduction of the influence of the dominant species (Bulleri et al. 2005). Then, we performed an analysis of similarities (ANOSIM; Clarke 1993) with a 2-way crossed layout for each coast, using untransformed data, to test for differences between elevation and exposure levels. The null hypothesis for the ANOSIM with a 2-way crossed layout is that there are no differences between levels of 1 factor allowing for the fact that there may be effects from the other factor. The ANOSIM test statistic (the global $R$ ) is a comparative measure of the degree of separation between groups: $R=1$ implies that all replicates within groups are more similar to each other than to any replicates from different groups, while $R \cong$ 0 implies little or no segregation into groups (Clarke \& Warwick 2001). We also performed an analysis of similarity percentages (SIMPER; Clarke 1993) for each coast. SIMPER identifies the species that are most responsible for the observed patterns (e.g. the species that typify each level of a factor and those that contribute the most to the dissimilarity between levels) by disaggregating the Bray-Curtis similarities between samples. The more abundant a species is within a group, the more it contributes to the intra-group similarity, while a species with a consistently high contribution to the dissimilarity between groups is a good discriminating species (Clarke \& Warwick 2001).

\section{RESULTS}

\section{Gulf of St. Lawrence coast (SS)}

The ordination through NMDS revealed groupings of samples according to their elevation on the shore and the intensity of wave/ice exposure (Fig. 1). The 


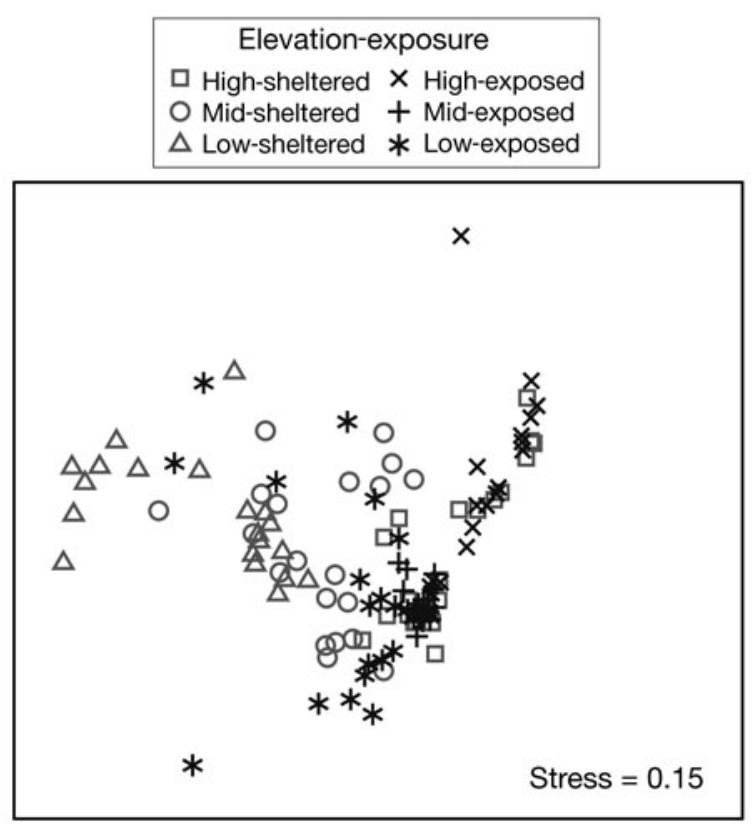

Fig. 1. Two-dimensional non-metric multidimensional scaling (NMDS) ordination of samples at Sea Spray Shore, Gulf of St. Lawrence, Nova Scotia, Canada. Patterns in community composition are revealed based on the similarities between 120 quadrats across combinations of levels of elevation and wave/ice exposure

2-way crossed ANOSIM test based on Bray-Curtis similarity coefficients confirmed such separations, showing significant effects of elevation and exposure ( $p<0.001$; Table 1). The global $R$-values for elevation and exposure were similar, suggesting that both factors exerted a similar influence on community composition. There were also significant differences between all pairs of elevation groups ( $p<0.001$; Table 1$)$, with the strongest separation occurring between the high and low intertidal zones.

The SIMPER analysis identified the species that typified levels of each factor (Table 2) and the species that were most responsible for distinctions between factor levels (Table 3). The average similarity was $49 \%$ for the high-intertidal group, $63 \%$ for the mid-intertidal group, and $47 \%$ for the low-intertidal group. The aver-

Table 1. Summary of ANOSIM results for Sea Spray Shore, Gulf of St. Lawrence, Nova Scotia, Canada $(p<0.001$ for all tests)

\begin{tabular}{|lc|}
\hline Test & $R$ statistic \\
\hline Global for elevation & 0.456 \\
High, mid & 0.399 \\
High, low & 0.616 \\
Mid, low & 0.384 \\
Global for exposure & 0.429 \\
\hline
\end{tabular}

age dissimilarity was $61 \%$ between high and mid elevations, $78 \%$ between high and low elevations, and $60 \%$ between mid and low elevations. The average similarity was $48 \%$ for the sheltered group and $58 \%$ for the exposed group. The average dissimilarity between both exposure groups was $64 \%$. The barnacle Semibalanus balanoides consistently contributed the most to within-group similarity and between-group dissimilarities. The brown seaweeds Ascophyllum nodosum, Fucus spp., and Chordaria flagelliformis, and the red seaweed Chondrus crispus were also important contributors to either within-group similarity, between-group dissimilarity, or both (Tables $2 \& 3$ ).

\section{Atlantic coast (TB)}

The NMDS ordination also revealed clustering of samples according to their elevation on the shore and degree of wave exposure (Fig. 2). The 2-way ANOSIM test confirmed these separations ( $p<0.001$; Table 4 ). The global $R$-value for elevation was only about $17 \%$ lower than that for exposure. There were significant differences between all pairs of groups $(p<0.001$; Table 4), with the strongest separations occurring between high and low elevations and between sheltered and exposed habitats.

The SIMPER analysis identified the species that typified each group (Table 5) and those that distinguished between factor levels (Table 6). The average similarity

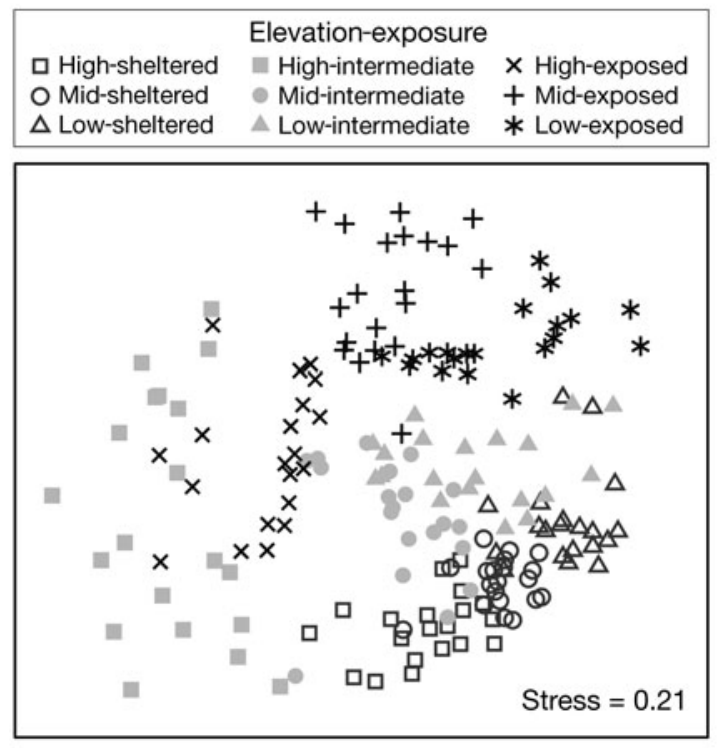

Fig. 2. Two-dimensional NMDS ordination of samples at Tor Bay Provincial Park, Atlantic coast of Nova Scotia, Canada. Patterns in community composition are revealed based on the similarities between 180 quadrats across combinations of levels of elevation and wave exposure 
was $37 \%$ for the high-intertidal group, $54 \%$ for the mid-intertidal group, and $47 \%$ for the low-intertidal group. Ascophyllum nodosum contributed the most to the within-group similarity for all elevations. The crustose red alga Hildenbrandia rubra was generally the next most important species, while Chondrus crispus was important at low elevations (Table 5). The average dissimilarity was $77 \%$ between high and mid elevations, $83 \%$ between high and low elevations, and $61 \%$ between mid and low elevations, with $H$. rubra contributing the most to between-group dissimilarities (Table 6). The average similarity was $57 \%$ for the sheltered group, $40 \%$ for the intermediate-exposure group, and $42 \%$ for the exposed group. A. nodosum contributed the most to the sheltered group, while $H$. rubra contributed the most to the intermediateexposure and exposed groups (Table 5). The average dissimilarity was $74 \%$ between the sheltered and intermediate-exposure groups and $86 \%$ between the sheltered and exposed groups, with the greatest contribution to explaining differences given by $A$.

Table 2. Summary of SIMPER results for Sea Spray Shore: average abundance (\% cover) of typifying species in each elevation and exposure group, their contribution (\%) to the within-group similarity, and cumulative total (\%) of contributions (90\% cut-off)

\begin{tabular}{|c|c|c|c|}
\hline & $\begin{array}{l}\text { Abun- } \\
\text { dance }\end{array}$ & $\begin{array}{l}\text { Contribu- } \\
\text { tion }\end{array}$ & $\begin{array}{l}\text { Cumula- } \\
\text { tive }\end{array}$ \\
\hline \multicolumn{4}{|l|}{ Elevation } \\
\hline \multicolumn{4}{|l|}{ High intertidal } \\
\hline Semibalanus balanoides & 45.21 & 91.70 & 91.70 \\
\hline \multicolumn{4}{|l|}{ Mid-intertidal } \\
\hline Semibalanus balanoides & 66.70 & 69.91 & 69.91 \\
\hline Ascophyllum nodosum & 23.44 & 9.86 & 79.78 \\
\hline Fucus vesiculosus & 18.13 & 5.60 & 85.38 \\
\hline Mytilus edulis & 6.46 & 4.23 & 89.61 \\
\hline Fucus spp. & 4.53 & 2.49 & 92.10 \\
\hline \multicolumn{4}{|l|}{ Low intertidal } \\
\hline Semibalanus balanoides & 45.70 & 34.40 & 34.40 \\
\hline Fucus serratus & 37.36 & 33.15 & 67.54 \\
\hline Chondrus crispus & 14.65 & 9.02 & 76.56 \\
\hline Chordaria flagelliformis & 17.99 & 7.02 & 83.58 \\
\hline Ascophyllum nodosum & 13.33 & 3.93 & 87.51 \\
\hline Hildenbrandia rubra & 8.64 & 2.77 & 90.28 \\
\hline \multicolumn{4}{|l|}{ Exposure } \\
\hline \multicolumn{4}{|l|}{ Sheltered } \\
\hline Semibalanus balanoides & 46.99 & 47.03 & 47.03 \\
\hline Fucus serratus & 28.35 & 22.35 & 69.38 \\
\hline Ascophyllum nodosum & 26.19 & 12.05 & 81.43 \\
\hline Fucus vesiculosus & 15.25 & 5.18 & 86.60 \\
\hline Chondrus crispus & 6.65 & 3.42 & 90.03 \\
\hline \multicolumn{4}{|l|}{ Exposed } \\
\hline Semibalanus balanoides & 58.08 & 82.30 & 82.30 \\
\hline Mytilus edulis & 5.66 & 3.95 & 86.25 \\
\hline Chordaria flagelliformis & 12.03 & 3.76 & 90.01 \\
\hline
\end{tabular}

nodosum (Table 6). The average dissimilarity was $79 \%$ between the intermediate-exposure and exposed groups, with the greatest contribution given by $H$. rubra (Table 6). The seaweeds Chondrus crispus, Fucus spp., green or brown (Ralfsia) crusts, and filamentous algal turfs were also important contributors to either within-group similarities, between-group dissimilarities, or both (Tables $5 \& 6$ ).

\section{DISCUSSION}

Our previous analysis of intertidal community structure at SS and TB indicated that richness varied across vertical and horizontal gradients of environmental stress (Scrosati \& Heaven 2007). Those results agreed with predictions from an environmental stress model proposed by Menge \& Sutherland (1987) and further developed by Bruno et al. (2003). Richness, however, remained statistically similar for certain ranges across the studied gradients. As a result of uncorrelated changes in species abundance between consecutive levels of stress (see Tables 1 \& 2 in Scrosati \& Heaven 2007), community composition did change across all studied ranges of elevation and exposure, as shown by our multivariate analyses. Thus, even moderate changes in abiotic stress seem capable of altering the structure of intertidal communities. Along this line, our multivariate tests also identified stronger effects of exposure on community structure than previously found by considering richness alone. While elevation explained a relatively high percentage of the spatial variation in richness (39\% at SS and $41 \%$ at TB), exposure contributed little $\left(10 \%\right.$ at SS and $12 \%$ at $\mathrm{TB}_{\text {; }}$ Scrosati \& Heaven 2007). However, the multivariate analyses identified relatively high (and comparable in magnitude) effects of elevation and exposure on community composition at both SS and TB, as indicated by $R$-values (Tables 1 \& 4).

Our multivariate analyses also distinguished communities between sites that had the same richness but that were environmentally different because of different stressors varying in opposite ways. For example, at $\mathrm{TB}$, richness was similar (an average of 14 taxa per quadrat) between mid-intertidal elevations subjected to intermediate wave exposure and low elevations subjected to high exposure (Scrosati \& Heaven 2007). Determining differences in environmental stress between sites is difficult when some stressors are negatively correlated across space (Eckersley 2007). However, it could be argued that the average degree of stress might be similar at the 2 environments mentioned above, since one is subjected to a higher degree of physical stress (high vs. intermediate wave exposure) while the other is subjected to a higher degree of 
Table 3. Summary of SIMPER results for Sea Spray Shore: average abundance (\% cover) of discriminating species in each elevation and exposure group, their contribution (\%) to the dissimilarity between groups, and cumulative total (\%) of contributions (90\% cut-off)

\begin{tabular}{|c|c|c|c|c|}
\hline \multirow[b]{2}{*}{ Elevation } & \multicolumn{2}{|c|}{ Abundance } & \multirow[t]{2}{*}{ Contribution } & \multirow[t]{2}{*}{ Cumulative } \\
\hline & High & Mid & & \\
\hline Semibalanus balanoides & 45.21 & 66.70 & 45.06 & 45.06 \\
\hline Ascophyllum nodosum & 2.88 & 23.44 & 14.17 & 59.22 \\
\hline Fucus vesiculosus & 2.63 & 18.13 & 10.92 & 70.15 \\
\hline Mytilus edulis & 2.30 & 6.46 & 6.32 & 76.46 \\
\hline Fucus serratus & 0 & 8.50 & 4.75 & 81.22 \\
\hline Fucus spp. & 2.60 & 4.53 & 4.74 & 85.95 \\
\hline Epiphytic brown algae & 0.38 & 6.29 & 3.64 & 89.59 \\
\hline \multirow[t]{2}{*}{ Hildenbrandia rubra } & 0.45 & 4.35 & 3.53 & 93.12 \\
\hline & High & Low & & \\
\hline Semibalanus balanoides & 45.21 & 45.70 & 27.52 & 27.52 \\
\hline Fucus serratus & 0 & 37.36 & 21.99 & 49.51 \\
\hline Chordaria flagelliformis & 0 & 17.99 & 10.53 & 60.04 \\
\hline Chondrus crispus & 0 & 14.65 & 9.15 & 69.18 \\
\hline Ascophyllum nodosum & 2.88 & 13.33 & 5.86 & 75.05 \\
\hline Hildenbrandia rubra & 0.45 & 8.64 & 4.92 & 79.96 \\
\hline Epiphytic brown algae & 0.38 & 9.11 & 4.11 & 84.08 \\
\hline Mytilus edulis & 2.30 & 3.93 & 3.23 & 87.30 \\
\hline Dynamena pumila & 0.01 & 4.43 & 2.23 & 89.53 \\
\hline \multirow[t]{2}{*}{ Fucus spp. } & 2.60 & 1.63 & 2.21 & 91.75 \\
\hline & Mid & Low & & \\
\hline Semibalanus balanoides & 66.70 & 45.70 & 21.16 & 21.16 \\
\hline Fucus serratus & 8.50 & 37.36 & 16.02 & 37.18 \\
\hline Ascophyllum nodosum & 23.44 & 13.33 & 10.29 & 47.46 \\
\hline Chordaria flagelliformis & 0.39 & 17.99 & 10.19 & 57.65 \\
\hline Fucus vesiculosus & 18.13 & 2.13 & 7.77 & 65.43 \\
\hline Chondrus crispus & 0.96 & 14.65 & 7.75 & 73.18 \\
\hline Epiphytic brown algae & 6.29 & 9.11 & 6.09 & 79.27 \\
\hline Hildenbrandia rubra & 4.35 & 8.64 & 5.24 & 84.51 \\
\hline Mytilus edulis & 6.46 & 3.93 & 3.55 & 88.06 \\
\hline Fucus spp. & 4.53 & 1.63 & 2.86 & 90.92 \\
\hline Exposure & Sheltered & Exposed & & \\
\hline Semibalanus balanoides & 46.99 & 58.08 & 34.71 & 34.71 \\
\hline Ascophyllum nodosum & 26.19 & 0.23 & 13.85 & 48.55 \\
\hline Fucus serratus & 28.35 & 2.23 & 13.09 & 61.65 \\
\hline Fucus vesiculosus & 15.25 & 0 & 8.17 & 69.82 \\
\hline Chordaria flagelliformis & 0.23 & 12.03 & 5.23 & 75.05 \\
\hline Mytilus edulis & 2.80 & 5.66 & 4.21 & 79.26 \\
\hline Epiphytic brown algae & 4.83 & 5.68 & 3.97 & 83.23 \\
\hline Hildenbrandia rubra & 5.89 & 3.07 & 3.78 & 87.01 \\
\hline Fucus spp. & 2.84 & 2.99 & 3.01 & 90.02 \\
\hline
\end{tabular}

abundant at least in certain habitats. All of the mobile species (i.e. grazers and predators) occurred in low abundances and thus contributed little to explaining similarities and dissimilarities. Because of their harsh winter conditions (Bertness 2007), northern Nova Scotia shores depict intermediate-to-high levels of environmental stress along the complete stress gradient where the cold-temperate intertidal biota occurs in the NW Atlantic. Thus, our findings support the notion that, for a given regional set of species, mobile consumers tend not to be abundant in relatively stressful habitats (Menge \& Sutherland 1987).

At SS, barnacles Semibalanus balanoides constituted the main characterizing species, accounting for a large proportion of similarities and dissimilarities. This species was by far the most dominant in terms of cover. A large proportion of barnacle cover in the summer (when we took our measurements) is given by recruits, which appear on the coast in the spring. A significant proportion of the barnacles that are recruited every spring die in the following winter as a result of ice scour (MacPherson et al. 2008), but barnacles nonetheless remain as potentially important organisms in these communities (McKindsey \& Bourget 2001). For example, their high levels of space occupancy in summer might limit substrate colonization by other species, while the high abundance of recruits may contribute to sustain populations of predators, such as whelks. The high contribution of barnacles to dissimilarities between elevations resulted from their vertical changes in cover, which appears to be determined in part by verti- physiological stress (mid vs. low elevation). Nonetheless, both habitats differed clearly in community composition, as shown by our NMDS ordination. Such a difference makes sense when it is recognized that different species normally perform differently under different combinations of levels of environmental factors (Chase \& Leibold 2003).

The SIMPER analyses identified the species that most contributed to explaining the similarities within environments and dissimilarities between environments on both studied coasts. In general terms, it is worth noting that the species with the highest contributions were sessile (seaweeds and filter feeders) and
Table 4. Summary of ANOSIM results for Tor Bay Provincial Park, Atlantic coast of Nova Scotia, Canada ( $p<0.001$ for all tests)

\begin{tabular}{|lc|}
\hline Test & $R$ statistic \\
\hline Global for elevation & 0.550 \\
High, mid & 0.651 \\
High, low & 0.725 \\
Mid, low & 0.355 \\
Global for exposure & 0.663 \\
Sheltered, intermediate & 0.604 \\
Sheltered, exposed & 0.838 \\
Intermediate, exposed & 0.543 \\
\hline
\end{tabular}


Table 5. Summary of SIMPER results for Tor Bay Provincial Park: average abundance (\% cover) of typifying species in each elevation and exposure group, their contribution (\%) to the within-group similarity, and the cumulative total (\%) of contributions (90\% cut-off)

\begin{tabular}{|c|c|c|c|}
\hline & Abundance & Contribution & Cumulative \\
\hline \multicolumn{4}{|l|}{ Elevation } \\
\hline \multicolumn{4}{|l|}{ High intertidal } \\
\hline Ascophyllum nodosum & 16.50 & 27.10 & 27.10 \\
\hline Hildenbrandia rubra & 13.58 & 24.21 & 51.31 \\
\hline Filamentous algal turf & 5.18 & 11.44 & 62.75 \\
\hline Semibalanus balanoides & 2.72 & 9.34 & 72.10 \\
\hline Fucus vesiculosus & 5.83 & 6.88 & 78.98 \\
\hline Littorina saxatilis & 0.49 & 4.22 & 83.20 \\
\hline Littorina littorea & 0.29 & 3.09 & 86.29 \\
\hline Green algal crust & 3.23 & 2.87 & 89.16 \\
\hline Fucus spp. & 2.38 & 2.76 & 91.92 \\
\hline \multicolumn{4}{|l|}{ Mid-intertidal } \\
\hline Ascophyllum nodosum & 39.65 & 35.10 & 35.10 \\
\hline Hildenbrandia rubra & 31.46 & 21.64 & 56.74 \\
\hline Ralfsia sp. & 20.78 & 11.68 & 68.43 \\
\hline Filamentous algal turf & 15.17 & 7.19 & 45.62 \\
\hline Epiphytic brown algae & 13.00 & 6.37 & 81.99 \\
\hline Fucus spp. & 11.88 & 4.81 & 86.79 \\
\hline Dynamena pumila & 5.80 & 2.68 & 89.48 \\
\hline Fucus vesiculosus & 7.66 & 2.50 & 91.97 \\
\hline \multicolumn{4}{|l|}{ Low intertidal } \\
\hline Ascophyllum nodosum & 34.50 & 24.77 & 24.77 \\
\hline Chondrus crispus & 32.47 & 20.38 & 45.14 \\
\hline Hildenbrandia rubra & 31.30 & 18.19 & 63.33 \\
\hline Corallina officinalis & 17.72 & 8.97 & 72.30 \\
\hline Fucus spp. & 17.79 & 8.57 & 80.88 \\
\hline Epiphytic brown algae & 9.17 & 3.81 & 84.69 \\
\hline \multicolumn{4}{|l|}{ Exposure } \\
\hline \multicolumn{4}{|l|}{ Sheltered } \\
\hline Ascophyllum nodosum & 73.02 & 64.15 & 64.15 \\
\hline Chondrus crispus & 13.66 & 6.22 & 70.37 \\
\hline Hildenbrandia rubra & 11.73 & 5.76 & 76.12 \\
\hline Fucus vesiculosus & 9.46 & 5.36 & 81.48 \\
\hline Dynamena pumila & 8.58 & 3.27 & 84.75 \\
\hline Epiphytic brown algae & 5.06 & 2.50 & 87.26 \\
\hline Lithothamnion sp. & 3.81 & 2.28 & 89.54 \\
\hline Green algal crust & 5.63 & 2.27 & 91.81 \\
\hline \multicolumn{4}{|l|}{ Intermediate } \\
\hline Hildenbrandia rubra & 36.84 & 41.49 & 41.49 \\
\hline Ascophyllum nodosum & 17.50 & 10.45 & 51.93 \\
\hline Chondrus crispus & 12.18 & 9.00 & 60.93 \\
\hline Filamentous algal turf & 2.18 & 7.61 & 68.53 \\
\hline Semibalanus balanoides & 2.13 & 6.00 & 74.53 \\
\hline Littorina littorea & 2.28 & 4.88 & 79.41 \\
\hline Fucus vesiculosus & 10.73 & 4.61 & 84.02 \\
\hline Epiphytic brown algae & 5.12 & 4.17 & 88.19 \\
\hline Littorina saxatilis & 0.18 & 3.04 & 91.23 \\
\hline \multicolumn{4}{|l|}{ Exposed } \\
\hline Hildenbrandia rubra & 27.76 & 22.76 & 22.76 \\
\hline Fucus spp. & 28.07 & 16.06 & 38.82 \\
\hline Ralfsia sp. & 20.40 & 15.10 & 53.92 \\
\hline Filamentous algal turf & 20.75 & 13.39 & 67.31 \\
\hline Chondrus crispus & 10.84 & 7.68 & 74.99 \\
\hline Corallina officinalis & 10.82 & 6.40 & 81.39 \\
\hline Epiphytic brown algae & 12.52 & 5.42 & 86.81 \\
\hline Polysiphonia sp. & 4.29 & 2.28 & 89.09 \\
\hline Semibalanus balanoides & 1.24 & 2.17 & 91.26 \\
\hline
\end{tabular}

cal differences in predator pressure (MacPherson \& Scrosati 2008).

At SS, 4 brown seaweeds (Ascophyllum nodosum, Fucus serratus, F. vesiculosus, and Chordaria flagelliformis) and 1 red seaweed (Chondrus crispus) were the next organisms in importance as characterizing species. The 4 brown algae were useful in discriminating exposed from sheltered habitats, although for different reasons: while the 3 fucoid species predominated in sheltered habitats, C. flagelliformis did so in exposed habitats. A. nodosum might be limited to sheltered habitats by its low resistance to wave action (Cousens 1985, Vadas et al. 1990) and ice scour (Mathieson et al. 1982, Åberg 1992). On the milder shores of $\mathrm{New}$ England, A. nodosum predominates in wavesheltered habitats because of the competitive release from mussels Mytilus spp., which would naturally exclude other space holders but are controlled by intense predation by whelks Nucella lapillus and sea stars Asterias spp. (Lubchenco \& Menge 1978, Bertness et al. 2004). In sheltered habitats at SS, mussels occur in low abundances but seem to be more limited by the harsh winters than by predators, since whelks and sea stars are uncommon in those areas (Scrosati \& Heaven 2007). Thus, mostly intraspecific factors appear to explain the marked change in $A$. nodosum abundance across the exposure gradient at SS, which might apply to the other fucoid species as well. Differences between high and low elevations were mostly indicated by changes in the abundance of F. serratus, $C$. flagelliformis, and $C$. crispus, since these algae were almost restricted to low elevations. These patterns are consistent with those reported at lower latitudes along the NW Atlantic coast (Lubchenco 1980, Bertness et al. 2004, Adey \& Hayek 2005), although at SS these species generally occurred in lower abundance, possibly because of the disturbance caused by sea ice every winter. C. crispus may be restricted to low elevations because of its low resistance to desiccation stress (Lubchenco 1980).

Mussels (only Mytilus edulis at $\mathrm{SS}$, as indicated by DNA analyses; J. C. Tam \& R. A. Scrosati unpubl. data) had a low percent contribution because of their consistently low abundance. At SS, mussels are mostly restricted to crevices and cracks, likely as a result of ice scour every winter (McKindsey \& Bourget 2001). Thus, the ecological role of mussels on the Gulf of St. Lawrence coast is likely lower 
than on more southern shores along the NW Atlantic coast, where mussels usually thrive under moderate or high levels of wave exposure (Lubchenco \& Menge 1978, Hunt \& Scheibling 2001, Bertness et al. 2004).

At TB, barnacles were unimportant as a characterizing species, as they occurred in rather low abundance even when including the recruits. The causes of the high difference in barnacle abundance between the open Atlantic (TB) and Gulf of St. Lawrence (SS) coasts are unclear. Differences in food supply (phytoplankton) might explain such a pattern, as the concentration of chlorophyll a (a common surrogate for phytoplankton biomass) is generally higher on the southern Gulf of St. Lawrence coast than on the open Atlantic coast of Nova Scotia (Devred et al. 2007, NASA 2008).

At TB, the main characterizing species were seaweeds: Ascophyllum nodosum, Hildenbrandia rubra, Chondrus crispus, and species of Fucus (excluding F. serratus, which was largely absent at TB). A. nodosum was good at discriminating habitats differing in wave exposure, as its abundance decreased sharply from sheltered to exposed habitats, where it was virtually absent (as at SS). Due to their size and structural complexity, stands of $A$. nodosum in sheltered environments create suitable microhabitat conditions for a number of small species (Johnson \& Scheibling 1987, Bertness et al. 1999), thus making A. nodosum an important ecosystem engineer. C. crispus was useful at separating elevations (as at SS), as its abundance decreased dramatically with increasing elevation. The species of Fucus helped to distinguish between exposure levels, as they were generally more abundant towards exposed habitats, possibly as a result of competitive release from $A$. nodosum, which was almost absent in such places. The crustose red alga $H$. rubra was useful at distinguishing levels across the elevation and exposure gradients, since it peaked in abundance in mid-intertidal habitats subjected to intermediate wave action. This species
Table 6. Summary of SIMPER results for Tor Bay Provincial Park: average abundance (\% cover) of discriminating species in each elevation and exposure group, their contribution (\%) to the dissimilarity between groups, and the cumulative total (\%) of contributions (90\% cut-off)

\begin{tabular}{|c|c|c|c|c|}
\hline & \multicolumn{2}{|c|}{ Abundance } & \multirow[t]{2}{*}{ Contribution } & \multirow[t]{2}{*}{ Cumulative } \\
\hline Elevation & High & Mid & & \\
\hline Hildenbrandia rubra & 13.58 & 31.46 & 24.30 & 24.30 \\
\hline Ascophyllum nodosum & 16.50 & 39.65 & 16.43 & 40.72 \\
\hline Ralfsia sp. & 0.38 & 20.78 & 10.17 & 50.89 \\
\hline Filamentous algal turf & 5.18 & 15.17 & 8.66 & 59.55 \\
\hline Epiphytic brown algae & 0.53 & 13.00 & 7.19 & 66.74 \\
\hline Fucus vesiculosus & 5.83 & 7.66 & 6.49 & 73.24 \\
\hline Fucus spp. & 2.38 & 11.88 & 6.18 & 79.42 \\
\hline Green algal crust & 3.23 & 3.20 & 3.22 & 82.64 \\
\hline Dynamena pumila & 1.08 & 5.80 & 2.72 & 85.36 \\
\hline Chondrus crispus & 0.02 & 4.19 & 2.43 & 87.78 \\
\hline \multirow[t]{2}{*}{ Semibalanus balanoides } & 2.72 & 1.67 & 2.21 & 90.00 \\
\hline & High & Low & & \\
\hline Hildenbrandia rubra & 13.58 & 31.30 & 18.68 & 18.68 \\
\hline Chondrus crispus & 0.02 & 32.47 & 18.21 & 36.90 \\
\hline Ascophyllum nodosum & 16.50 & 34.50 & 11.99 & 48.88 \\
\hline Corallina officinalis & 0 & 17.72 & 8.65 & 57.53 \\
\hline Fucus spp. & 2.38 & 17.79 & 8.10 & 65.63 \\
\hline Fucus vesiculosus & 5.83 & 6.70 & 5.96 & 71.59 \\
\hline Epiphytic brown algae & 0.53 & 9.17 & 4.06 & 75.65 \\
\hline Lithothamnion sp. & 0 & 7.16 & 3.64 & 79.29 \\
\hline Filamentous algal turf & 5.18 & 2.58 & 3.37 & 82.67 \\
\hline Green algal crust & 3.23 & 1.28 & 1.97 & 84.64 \\
\hline Polysiphonia sp. & 0 & 3.57 & 1.78 & 86.43 \\
\hline Littorina littorea & 0.29 & 2.86 & 1.54 & 87.97 \\
\hline Membranipora sp. & 0 & 2.85 & 1.38 & 89.35 \\
\hline \multirow[t]{2}{*}{ Semibalanus balanoides } & 2.72 & 0.43 & 1.33 & 90.68 \\
\hline & Mid & Low & & \\
\hline Hildenbrandia rubra & 31.46 & 31.30 & 15.09 & 15.09 \\
\hline Chondrus crispus & 4.19 & 32.47 & 14.81 & 29.90 \\
\hline Ascophyllum nodosum & 39.65 & 34.50 & 10.73 & 40.63 \\
\hline Ralfsia sp. & 20.78 & 0 & 8.24 & 48.86 \\
\hline Corallina officinalis & 0.91 & 17.72 & 7.55 & 56.41 \\
\hline Fucus spp. & 11.88 & 17.79 & 6.75 & 63.16 \\
\hline Epiphytic brown algae & 13.00 & 9.17 & 5.44 & 68.60 \\
\hline Fucus vesiculosus & 7.66 & 6.70 & 5.39 & 73.99 \\
\hline Filamentous algal turf & 15.17 & 2.58 & 5.32 & 79.31 \\
\hline Lithothamnion sp. & 1.64 & 7.16 & 3.02 & 82.33 \\
\hline Dynamena pumila & 5.80 & 2.18 & 2.43 & 84.76 \\
\hline Green algal crust & 3.20 & 1.28 & 1.97 & 86.73 \\
\hline Polysiphonia sp. & 0.98 & 3.57 & 1.60 & 88.34 \\
\hline Membranipora sp. & 0.14 & 2.85 & 1.29 & 89.63 \\
\hline Littorina littorea & 1.43 & 2.86 & 1.22 & 90.85 \\
\hline Exposure & Sheltered & Intermediate & & \\
\hline Ascophyllum nodosum & 73.02 & 17.50 & 36.71 & 36.71 \\
\hline Hildenbrandia rubra & 11.73 & 36.84 & 16.20 & 52.91 \\
\hline Fucus vesiculosus & 9.46 & 10.73 & 11.53 & 64.44 \\
\hline Chondrus crispus & 13.66 & 12.18 & 5.21 & 69.65 \\
\hline Green algal crust & 5.63 & 1.96 & 4.50 & 74.15 \\
\hline Dynamena pumila & 8.58 & 0.42 & 3.88 & 78.03 \\
\hline Filamentous algal turf & 0 & 2.18 & 2.90 & 80.93 \\
\hline Fucus spp. & 0.82 & 3.17 & 2.47 & 83.40 \\
\hline Epiphytic brown algae & 5.06 & 5.12 & 2.44 & 85.84 \\
\hline Semibalanus balanoides & 1.44 & 2.13 & 2.05 & 87.88 \\
\hline Corallina officinalis & 5.76 & 2.05 & 1.90 & 89.78 \\
\hline Lithothamnion sp. & 3.81 & 1.24 & 1.45 & 91.23 \\
\hline
\end{tabular}

continued on next page 
Table 6 (continued)

\begin{tabular}{|c|c|c|c|c|}
\hline & \multicolumn{2}{|c|}{ Abundance } & \multirow[t]{2}{*}{ Contribution } & \multirow[t]{2}{*}{ Cumulative } \\
\hline & Sheltered & Exposed & & \\
\hline Ascophyllum nodosum & 73.02 & 0.13 & 29.14 & 29.14 \\
\hline Hildenbrandia rubra & 11.73 & 27.76 & 12.08 & 41.21 \\
\hline Fucus spp. & 0.82 & 28.07 & 9.17 & 50.39 \\
\hline Filamentous algal turf & 0 & 20.75 & 7.77 & 58.16 \\
\hline Ralfsia sp. & 0.75 & 20.40 & 6.63 & 64.78 \\
\hline Fucus vesiculosus & 9.46 & 0 & 5.60 & 70.39 \\
\hline Chondrus crispus & 13.66 & 10.84 & 3.70 & 74.09 \\
\hline Epiphytic brown algae & 5.06 & 12.52 & 3.41 & 77.50 \\
\hline Corallina officinalis & 5.76 & 10.82 & 3.09 & 80.59 \\
\hline Dynamena pumila & 8.58 & 0.06 & 2.84 & 83.43 \\
\hline Green algal crust & 5.63 & 0.13 & 2.75 & 86.18 \\
\hline Lithothamnion sp. & 3.81 & 3.75 & 1.70 & 87.88 \\
\hline Polysiphonia sp. & 0.25 & 4.29 & 1.34 & 89.22 \\
\hline \multirow[t]{2}{*}{ Scytosiphon sp. } & 0 & 3.29 & 1.27 & 90.49 \\
\hline & Intermediate & Exposed & & \\
\hline Hildenbrandia rubra & 36.84 & 27.76 & 25.95 & 25.95 \\
\hline Filamentous algal turf & 2.18 & 20.75 & 13.44 & 39.39 \\
\hline Fucus spp. & 3.17 & 28.07 & 11.17 & 50.56 \\
\hline Ralfsia sp. & 0 & 20.40 & 7.58 & 58.13 \\
\hline Ascophyllum nodosum & 17.50 & 0.13 & 6.61 & 64.75 \\
\hline Chondrus crispus & 12.18 & 10.84 & 4.49 & 69.24 \\
\hline Epiphytic brown algae & 5.12 & 12.52 & 4.04 & 73.28 \\
\hline Corallina officinalis & 2.05 & 10.82 & 3.63 & 76.91 \\
\hline Fucus vesiculosus & 10.73 & 0 & 3.62 & 80.53 \\
\hline Calothrix sp. & 0.29 & 1.74 & 2.93 & 83.46 \\
\hline Semibalanus balanoides & 2.13 & 1.24 & 2.65 & 86.11 \\
\hline Scytosiphon sp. & 0 & 3.29 & 1.75 & 87.87 \\
\hline Polysiphonia sp. & 0 & 4.29 & 1.56 & 89.43 \\
\hline Lithothamnion sp. & 1.24 & 3.75 & 1.48 & 90.91 \\
\hline
\end{tabular}

function (Emery \& Gross 2007, Vaughn et al. 2007, Otto et al. 2008). Our multivariate analyses also identified the species that mainly characterized different environments. Such species were what are considered to be basal species (sessile organisms sustaining upper trophic levels; Pimm 1982), some of which may be locally relevant as ecosystem engineers (Crain \& Bertness 2006, Wright \& Jones 2006). The experimental work needed to unravel the interspecific interactions that determine community structure across the studied stress gradients might benefit by initially focusing on such characterizing species.

\begin{abstract}
Acknowledgements. We thank E. A. MacPherson and L. K. Eckersley for their assistance with field work and 3 anonymous reviewers for their valuable comments on the manuscript. Funding was provided by grants from the Canada Research Chair (CRC) program, the Canada Foundation for Innovation (CFI), the Natural Sciences and Engineering Research Council of Canada (NSERC), and the Saint Francis Xavier University Council for Research (UCR) to R.A.S.
\end{abstract}

\section{LITERATURE CITED}

and its ecological success seems to be related in part to its resistance to grazing by snails (Bertness et al. 1983, Chapman 1990). The markedly lower abundance of $H$. rubra at SS than at TB might result from the sea ice scouring the substrate every winter at SS.

Mussels (2 cryptic species on the Atlantic coast: Mytilus edulis and M. trossulus; J. C. Tam \& R. A. Scrosati unpubl. data) were unimportant at TB according to SIMPER, their abundance being even lower than at SS. This represents further evidence suggesting that the role of mussels in structuring intertidal communities in northern Nova Scotia might be considerably less important than on more southern shores, which are subjected to milder environmental conditions (Bertness 2007).

In summary, our multivariate analyses of species composition were able to detect spatial changes in community structure that were not detected previously by univariate analyses of richness. Field experiments should determine whether the observed compositional changes are related to changes in the structure of interaction webs and, thus, in community
Åberg P (1992) A demographic study of two populations of the seaweed Ascophyllum nodosum. Ecology 73:1473-1487

Adey WH, Hayek LC (2005) The biogeographic structure of the western North Atlantic rocky intertidal. Cryptogam Algol 26:35-66

> Anderson MJ (2001) A new method for non-parametric multivariate analysis of variance. Austral Ecol 26:32-46

> Barnes DKA (1999) The influence of ice on polar nearshore benthos. J Mar Biol Assoc UK 79:401-407

> Benedetti-Cecchi L, Bertocci I, Vaselli S, Maggi E (2006) Temporal variance reverses the impact of high mean intensity of stress in climate change experiments. Ecology 87:2489-2499

Bertness MD (2007) Atlantic shorelines. Natural history and ecology. Princeton University Press, Princeton, NJ

Bertness MD, Yund PO, Brown AF (1993) Snail grazing and the abundance of algal crusts on a sheltered New England rocky beach. J Exp Mar Biol Ecol 71:147-164

Bertness MD, Leonard GH, Levine JM, Schmidt PR, Ingraham AO (1999) Testing the relative contribution of positive and negative interactions in rocky intertidal communities. Ecology 80:2711-2726

Bertness MD, Trussell GC, Ewanchuk PJ, Silliman BR (2004) Consumer-controlled community states on Gulf of Maine rocky shores. Ecology 85:1321-1331 
Bolton JJ (1983) Effects of short-term ice scouring on a Newfoundland rocky shore community. Astarte 12:39-43

Bruno JF, Stachowicz JJ, Bertness MD (2003) Inclusion of facilitation into ecological theory. Trends Ecol Evol 18: $119-125$

Bulleri F, Chapman MG, Underwood AJ (2005) Intertidal assemblages on seawalls and vertical rocky shores in Sydney Harbour, Australia. Austral Ecol 30:655-667

Chapman ARO (1990) Effects of grazing, canopy cover and substratum type on the abundances of common species of seaweeds inhabiting littoral fringe tide pools. Bot Mar 33: 319-326

> Chapman ARO, Johnson CR (1990) Disturbance and organization of macroalgal assemblages in the Northwest Atlantic. Hydrobiologia 192:77-121

Chase JM, Leibold MA (2003) Ecological niches. Linking classical and contemporary approaches. The University of Chicago Press, Chicago, IL

> Clarke KR (1993) Non-parametric multivariate analyses of changes in community structure. Aust J Ecol 18:117-143

Clarke KR, Warwick RM (2001) Change in marine communities: an approach to statistical analysis and interpretation. PRIMER-E, Plymouth

Cousens R (1985) Frond size distributions and the effects of the algal canopy on the behaviour of Ascophyllum nodosum (L.) Le Jolis. J Exp Mar Biol Ecol 92:231-249

Crain CM, Bertness MD (2006) Ecosystem engineering across environmental gradients: implications for conservation and management. Bioscience 56:211-218

Denny M (1995) Predicting physical disturbance: mechanistic approaches to the study of survivorship on wave-swept shores. Ecol Monogr 65:371-418

Devred E, Sathyendranath S, Platt T (2007) Delineation of ecological provinces using ocean colour radiometry. Mar Ecol Prog Ser 346:1-13

Downing AL, Leibold MA (2002) Ecosystem consequences of species richness and composition in pond food webs. Nature 416:837-841

Eckersley LK (2007) Assessing environmental stress and testing community organization models using rocky intertidal habitats from Nova Scotia. MSc thesis, Saint Francis Xavier University, Antigonish, NS

Emery SM, Gross KL (2007) Dominant species identity, not community evenness, regulates invasion in experimental grassland plant communities. Ecology 88:954-964

Fisheries and Oceans Canada (2008a) Temperature-Salinity Climatologies. Accessed 26 May. Available at: www.mar. dfo-mpo.gc.ca/science/ocean/tsdata.html

Fisheries and Oceans Canada (2008b) Marine Environmental Data Services. Accessed 26 May. Available at: www.medssdmm.dfo-mpo.gc.ca/meds/databases/wave/tdc_e.htm

Garbary DJ (2007) The margin of the sea: survival at the top of the tides. In: Seckbach J (ed) Algae and cyanobacteria in extreme environments. Springer-Verlag, Berlin, p 173-191

Gibson M (2003) Seashores of the Maritimes. Nimbus Publishing, Halifax, NS

> Gutt J (2001) On the direct impact of ice on marine benthic communities, a review. Polar Biol 24:553-564

Harley CDG, Helmuth BST (2003) Local- and regional-scale effects of wave exposure, thermal stress, and absolute versus effective shore level on patterns of intertidal zonation. Limnol Oceanogr 48:1498-1508

Heaven CS (2006) Patterns in rocky intertidal community structure on the northern and eastern shores of Nova Scotia. MSc thesis, Saint Francis Xavier University, Antigonish, NS

Helmuth B, Denny MW (2003) Predicting wave exposure in the rocky intertidal zone: do bigger waves always lead to larger forces? Limnol Oceanogr 48:1338-1345

Hunt HL, Scheibling RE (2001) Patch dynamics of mussels on rocky shores: integrating process to understand pattern. Ecology 82:3213-3231

Huston MA (1994) Biological diversity. The coexistence of species on changing landscapes. Cambridge University Press, Cambridge

Johnson LE (2007) Ice scour. In: Denny MW, Gaines SD (eds) Encyclopedia of tidepools \& rocky shores. University of California Press, Berkeley, CA, p 289-291

Johnson SC, Scheibling RE (1987) Structure and dynamics of epifaunal assemblages on intertidal macroalgae Ascophyllum nodosum and Fucus vesiculosus in Nova Scotia, Canada. Mar Ecol Prog Ser 37:209-227

Lubchenco J (1980) Algal zonation in the New England rocky intertidal community: an experimental analysis. Ecology 61:333-344

Lubchenco J, Menge BA (1978) Community development and persistence in a low rocky intertidal zone. Ecol Monogr 48: $67-94$

MacPherson EA, Scrosati R (2008) Population structure of the barnacle, Semibalanus balanoides (Cirripedia, Thoracica), across intertidal environmental stress gradients in northern Nova Scotia, Canada. Crustaceana 81:725-736

MacPherson EA, Scrosati R, Chareka P (2008) Barnacle recruitment on ice-scoured shores in eastern Canada. J Mar Biol Assoc UK 88:289-291

Martínez AJ (2003) Marine life of the North Atlantic: Canada to New England. Aqua Quest Publications, New York

Mathieson AC, Penniman CA, Busse PK, Tveter-Gallagher E (1982) Effects of ice on Ascophyllum nodosum within the Great Bay estuary system of New Hampshire-Maine. J Phycol 18:331-336

McKindsey CW, Bourget E (2001) Diversity of a northern rocky intertidal community: the influence of body size and succession. Ecology 82:3462-3478

Menge BA, Branch GM (2001) Rocky intertidal communities. In: Bertness MD, Gaines SD, Hay ME (eds) Marine community ecology. Sinauer, Sunderland, MA, p 221-251

> Menge BA, Sutherland JP (1987) Community regulation: variation in disturbance, competition, and predation in relation to environmental stress and recruitment. Am Nat 130: 730-757

Minchinton TE, Scheibling RE, Hunt HL (1997) Recovery of an intertidal assemblage following a rare occurrence of scouring by sea ice in Nova Scotia, Canada. Bot Mar 40: $139-148$

NASA (2008) SeaWiFS Project. Accessed 16 May. Available at: http://oceancolor.gsfc.nasa.gov/SeaWiFS/

Otto SB, Berlow EL, Rank NE, Smiley J, Brose U (2008) Predator diversity and identity drive interaction strength and trophic cascades in a food web. Ecology 89:134-144

Pimm SL (1982) Food webs. Chapman \& Hall, London

Pollock LW (1998) A practical guide to the marine animals of northeastern North America. Rutgers University Press, New Brunswick, NJ

Raffaelli D, Hawkins S (1996) Intertidal ecology. Chapman \& Hall, London

Saucier FJ, Roy F, Gilbert D, Pellerin P, Ritchie H (2003) Modeling the formation and circulation processes of water masses and sea ice in the Gulf of St. Lawrence, Canada. J Geophys Res 108, C8, 3269

- Scrosati R, Eckersley LK (2007) Thermal insulation of the intertidal zone by the ice foot. J Sea Res 58:331-334

> Scrosati R, Heaven C (2006) Field technique to quantify intensity of scouring by sea ice in rocky intertidal habitats. Mar 
Ecol Prog Ser 320:293-295

Scrosati R, Heaven C (2007) Spatial trends in community richness, diversity, and evenness across rocky intertidal environmental stress gradients in eastern Canada. Mar Ecol Prog Ser 342:1-14

Sears JR (1998) NEAS keys to the benthic marine algae of the northeastern coast of North America from Long Island Sound to the Strait of Belle Isle. Northeast Algal Society, Dartmouth, MA

Stachowicz JJ (2001) Mutualism, facilitation, and the structure of ecological communities. Bioscience 51:235-246

Sullivan G, Callaway JC, Zedler JB (2007) Plant assemblage composition explains and predicts how biodiversity affects salt marsh functioning. Ecol Monogr 77:569-590

Tilman D, Knops J, Wedin D, Reich P (2003) Plant diversity and composition: effects on productivity and nutrient dynamics on experimental grasslands. In: Loreau $\mathrm{M}$, Naeem S, Inchausti P (eds) Biodiversity and ecosystem functioning. Oxford University Press, Oxford, p 21-35

Editorial responsibility: Hans Heinrich Janssen, Oldendorf/Luhe, Germany
Tuomisto H, Ruokolainen K (2006) Analyzing or explaining beta diversity? Understanding the targets of different methods of analysis. Ecology 87:2697-2708

> Underwood AJ, Chapman MG, Connell SD (2000) Observations in ecology: you can't make progress on processes without understanding the patterns. J Exp Mar Biol Ecol 250:97-115

Vadas R, Wright W, Miller S (1990) Recruitment of AscophylIum nodosum: wave action as a source of mortality. Mar Ecol Prog Ser 61:263-272

> Vaughn CC, Spooner DE, Galbraith HS (2007) Contextdependent species identity effects within a functional group of filter-feeding bivalves. Ecology 88:1654-1662

Villalard-Bohnsack M (2003) Illustrated key to the seaweeds of New England. The Rhode Island Natural History Survey, Kingston, RI

Wright JP, Jones CG (2006) The concept of organisms as ecosystem engineers ten years on: progress, limitations, and challenges. Bioscience 56:203-209

Submitted: November 26, 2007; Accepted: July 14, 2008

Proofs received from author(s): September 17, 2008 